\title{
Performance measurement system using performance prism approach in batik company: a case study
}

\author{
Vembri Noor Helia*, Wahyudhi Sutrisno, Afriza Syawal Zaputra, Qurtubi \\ Department of Industrial Engineering, Universitas Islam Indonesia, Jl. Kaliurang Km. 14,5, Kabupaten Sleman, Daerah Istimewa \\ Yogyakarta 55584, Indonesia
}

\section{ARTICLE INFORMATION \\ Article history: \\ Received: March 4, 2021 \\ Revised: June 28, 2021 \\ Accepted: June 30, 2021 \\ Keywords: \\ Performance measurement \\ Performance prism \\ KPI \\ AHP \\ Stakeholder}

\section{A B S T R A C T}

$\mathrm{XYZ}$ company is one of the small-medium enterprises (SME) engaged in the batik industry with the main focus on making muslim clothes made from printed batik and batik. The company cannot evaluate the cause of the turnover decrease because no performance measurement has been applied. Therefore, a company performance measurement is carried out using the performance prism approach because a company performance appraisal is needed stakeholder contributions using the performance prism approach. Stakeholders of this company are consumers, employees, community, capital owners, and suppliers. Supporting the performance prism framework, the AHP method was used to determine the weighting and hierarchical structure and then carried out a scoring system with the help of OMAX to determine the company's actual score. This design shows that corporate stakeholders, including owners, consumers, employees, suppliers, and the surrounding community, obtained as many as 34 KPIs. From the implementation of the performance measurement system with OMAX scoring obtained the value of company performance based on satisfaction aspects (6.489), contribution aspect (6.582), and capability aspect (5.646). Recommendations are also given to improve it.

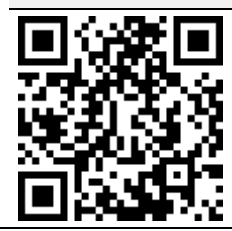

*Corresponding Author

Vembri Noor Helia

E-mail: vembri@uii.ac.id
This is an open-access article under the CC-BY-NC-SA license.

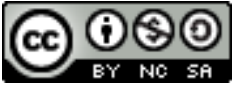

(C) 2021 Some rights reserved

\section{INTRODUCTION}

One industry that has rapid development in Indonesia is batik. The batik industry in Indonesia has experienced rapid development since the recognition of batik as a world cultural heritage by UNESCO on October 2, 2009. Batik gives important meaning for making the spirit of nationalism and can preserve Indonesian culture [1]. Micro and small businesses dominate the batik business. The batik industry was spread in almost all regions of Indonesia. An increase does not follow the increase in the number of batik industries in turnover. Especially in the current state of the Coronavirus Diseases (COVID-19) pandemic, many batik industries are experiencing a decline in turnover. Including XYZ company, which is one of the batik companies in Indonesia, its turnover also declined. $\mathrm{XYZ}$ company is one of the small-medium enterprises (SME) engaged in the batik industry with the main focus on making Muslim clothes made from printed batik and batik. The company cannot evaluate the cause of the turnover decrease because 
no performance measurement has been applied. Performance measurement with this system causes company orientation to focus only on short-term profits and neglects long-term survival.

There are several methods of measuring performance. These include performance pyramid systems, performance measurement systems for service industries, balanced scorecard, performance prism, organizational performance measurement, etc. [2]. One of the main weaknesses of the balanced scorecard approach is its incompleteness in identifying performance assessments of stakeholder contribution [3]. The performance measurement method with Performance Prism has advantages when compared to the BSC (Balanced Scorecard) method, which uses the identification of various interested stakeholders, including investors, suppliers, customers, labour, regulators, and the community. In contrast, the BSC only uses stakeholders from shareholders and customers courses. It compared to IPMS (Integrated Performance Measurement System), which directly uses several identifications regardless of whether the KPI comes from strategy, process, or capability; performance Prism has advantages, namely Key Performance Indicators (KPI). They are identified as consisting of strategic KPIs, process KPIs, and KPI capabilities [4].

In this study, performance measurement is measured using the performance prism approach. Performance prism is a performance measurement system that is a refinement of the previous performance measurement system. The framework from performance prism is categorized into two aspects: business performance review and performance measurement review [5]. Companies need strategies to deal with environmental conditions and consider the resources they have, for example, by using SWOT and Fuzzy [6]. This model is based not only on strategy but also on the satisfaction and contribution of stakeholders, processes, and company capabilities [7], [8]. It can be seen in Fig. 1 .
Contrary to the Balanced Scorecard performance measurement system, which is guided by performance measures strictly derived from strategy [9], [10]. Performance Prism refers to the needs and desires of the Stakeholders that must be considered first. Moreover, the Balanced Scorecard is more focused on financial results. It has not been able to determine the compensation system appropriately regarding the follow-up of the performance evaluation results [11]. Therefore, a company performance appraisal is needed stakeholder contributions using the performance prism. Stakeholders play an important role in improving SME performance through stakeholder functions as trainers, analysts, coordinators, specialists, and financial providers [12]. Performance prism also provides a comprehensive performance measurement by translating stakeholder satisfaction and contributions towards organizational goals, strategies, business processes, and capabilities, for example, in the batik industry [13]. The implementation of the Performance Prism method has been carried out too in various fields of micro and small business, including sports segments, pharmacy, department store, and an apparel faction [14].

A method of problem-solving is used to support decision-making using performance prism. The use of multi-criteria analysis is more popular than multi-objective optimization in environmentally conscious manufacturing. Currently, several techniques that are often used are AHP, ANP, and TOPSIS. Meanwhile, the use of other techniques such as MACBETH, DEMATEL, ELECTR, PROMETHEE is very rare [15]. This research using the Analytical Hierarchy Process (AHP) and the Scoring system method, Objective Matrix (OMAX). The use of AHP as a weighting criteria only. The advantage of AHP is that it guarantees consistency when determining the weight of the criteria. This study does not use a multi-criteria ranking index based on certain measures, such as the VIKOR method [16].

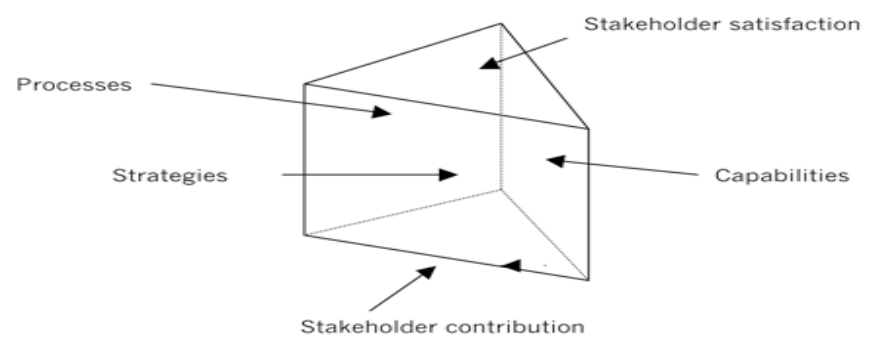

Fig 1. Performance prism scheme 
Many industries use a combination of the AHP method, such as automotive companies [17], the food industry [18], etc. The decision support model will describe complex multi-system or multicriteria problems into a hierarchy. Hierarchy is defined as a representation of a complex problem in a multi-level structure where the first level is the goal, followed by the system level, criteria, subsystems, and so on down to the last level of alternative criteria [19]. Various factors influence performance. It depends on the type and profile of the organization, and the aim of a study conducted [20]. Later, the OMAX method and the company's traffic light system can determine long-term goals regarding the goals to be addressed by the company.

This study aims to determine the satisfaction and contribution of each stakeholder to determine performance indicators of the criteria of strategy, processes, and capabilities of the company and design a performance measurement model and measure company performance based on the results of the design has been done. This performance measurement can help XYZ company to be able to carry out measurements and improvements so that it can develop into a better company and compete with various similar industries.

\section{RESEARCH METHODS}

The object of this research is one of the batik companies which has a "make to order" production system. Based on the source of data acquisition, the data needed are primary data and secondary data. Primary data includes a list of stakeholders, data on the causes of satisfaction of each stakeholder, strategies, processes, capabilities needed, and data on contributions from each stakeholder. Secondary data is obtained through specific references or literature regarding company data by conducting library research. Field studies were conducted through observation, interviews, and questionnaires. Stakeholders of this company are consumers, employees, community, capital owners, and suppliers. Data collection using a random sampling technique. Details of the number of respondents to consumers, employees, and communities are 50,65, and 70 respondents. The number of respondents has met the data adequacy test. There are two respondents for suppliers and one respondent for the capital owner.

The steps to use performance prism are as follows (Fig. 2):

1. Identify stakeholder satisfaction and contributions

Distributing questionnaires make the identification of satisfaction and contributions from the stakeholders so that the satisfaction and contribution data from the stakeholders will be obtained later. Customer satisfaction and questionnaire use a reference in the form of eight dimensions of quality: performance, features, reliability, performance, durability, serviceability, aesthetic, and perceived quality [21]. Ten random consumers were interviewing for the questionnaire to see what factors affect their satisfaction. The results of these interviews and adjusted to the reference journal, then used as a questionnaire of consumer satisfaction and contribution. Whereas employee satisfaction uses the reference of job satisfaction by Smith et al. [22], the five dimensions that affect job satisfaction are work itself, supervise, pay, promotion, and workers. As for the leading stakeholders, suppliers, and the community, satisfaction and contribution criteria are obtained using brainstorming and direct interviews with the parties concerned.

2. Transformation to the perspective of strategy and process

The next step is transforming data from satisfaction and contribution to the perspective of strategy and process. Satisfaction data and contributions have been obtained previously. It was transformed into a suitable strategy to be applied in the company. Brainstorming makes the determination of the company's strategy.

3. Determining the capability perspective and making Key Performance Indicators (KPIs) framework

The company's capability perspective is obtained by using data that has been collected and measured by the company before. This data is about business or KPI measurements that companies have previously carried out. From the data obtained previously and then processed with each perspective of performance prism, the overall company KPI framework will be obtained.

4. KPI weighting uses AHP and scoring by OMAX

KPI weighting used AHP and followed by the OMAX method to measure company performance based on the design results. AHP was developed by Saaty [23]. AHP is a technique to help solve complex problems by decomposing the problem into a hierarchy of levels. Each criterion is given a weight, and the alternatives are assessed in pairwise comparisons. 


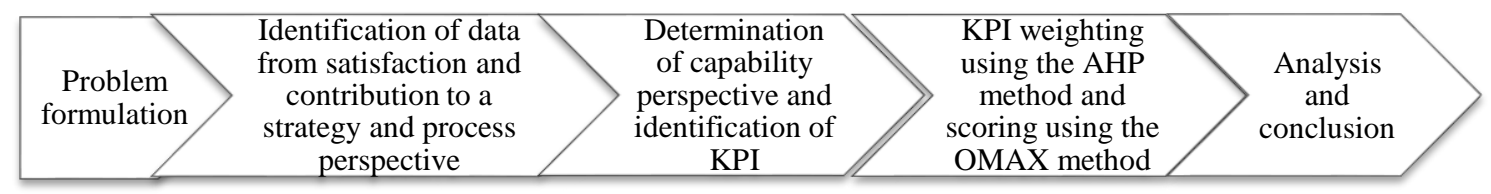

Fig. 2. Research stage

Then, priority is calculated using the eigenvector method. The steps for the AHP method are as follows:

1) Determine the types of criteria used.

2) Arrange these criteria in the form of a paired matrix.

$a_{i j}=\frac{w_{i}}{w_{j}}, i, j=1,2, \ldots, n$

Where: $\mathrm{n}$ is the number of criteria; $\mathrm{w}_{\mathrm{i}}$ is weighting to $i$, and aij is the ratio of the weight of $i$ and $j$. In filling out the pairwise comparison matrix, decision-makers are assisted by the scale shown in Table 1 . The scale describes the relative importance of an element over other elements concerning a criterion.

Table 1. Relative rating scale

\begin{tabular}{cl}
\hline $\begin{array}{c}\text { Level of } \\
\text { importance }\end{array}$ & \multicolumn{1}{c}{ Definition } \\
\hline 1 & $\begin{array}{l}\text { Both elements are very } \\
\text { important }\end{array}$ \\
3 & $\begin{array}{l}\text { One element is slightly more } \\
\text { important than the other }\end{array}$ \\
5 & $\begin{array}{l}\text { One element is very } \\
\text { important than the other }\end{array}$ \\
7 & $\begin{array}{l}\text { One element is more } \\
\text { important than the other }\end{array}$ \\
9 & $\begin{array}{l}\text { One element absolute is more } \\
\text { important than other elements } \\
\text { The middle value between } \\
\text { two consecutive assessments }\end{array}$ \\
\hline
\end{tabular}

3) Normalize each column by dividing each value between the $\mathrm{i}$-th column and $\mathrm{j}$-th row by the largest value in the $i$-th

$$
\hat{a}_{i j}=\frac{a_{i j}}{\operatorname{maxa}_{i j}}
$$

4) Add the values in each i-th column, i.e

$$
\hat{a}_{i}=\sum_{i} \hat{a}_{i j}
$$

5) Determine the priority weight of each i-th criterion by dividing each value by the number of compared criteria (n)

$\hat{w}_{i}=\frac{\hat{a}_{i}}{n}$

6) Calculating Lambda max (eigenvalue) with the formula:

$\lambda_{\text {max }}=\frac{C M}{n}$

Where: $\mathrm{CM}=$ Consistency Measure is obtained by multiplying the matrix by the priority weight of each row.

7) Calculating the Consistency Index (CI)

Counting the consistency is calculating the deviation from the consistency of the value of this deviation called the Consistency Index by using the equation:

$$
C I=\frac{\lambda_{\max }-n}{n-1}
$$

Where $: \lambda_{\max }$ : eigen value maximum, $\mathrm{n}$ : matrix size.

Consistency Index (CI) is a random matrix with a rating scale of 1 to 9 and the opposite as a Random Index (RI). Based on Saaty's calculation using 500 samples, if the numerical "judgment" is taken at random from a scale of $1 / 9,1 / 8, . ., 1,2, . ., 9$, a consistent average will be obtained for matrices with different sizes (Table 2). The comparison between $\mathrm{CI}$ and RI for a matrix is defined as Consistency Ratio (CR).

$C R=\frac{C I}{R I}$

In the AHP model, the comparison matrix can be accepted if the value of the consistency ratio $(\mathrm{CR}) \leq 0.1$.

8) Geometric average calculation

This step is carried out to find the average value of pairwise comparisons given by $n$ decision-makers with the following formula:

$a_{\mathrm{i}}=\left(Z_{1}, Z_{2}, \ldots Z_{\mathrm{n}}\right)^{1 / n}$

Where $\mathrm{a}_{\mathrm{i}}$ : the average value of the pairwise comparisons of criteria $i$ for $n$ participants 
(geometric mean), $\mathrm{Z}_{\mathrm{i}}$ : the average value of comparisons between criteria for participants $\mathrm{I}, \mathrm{n}$ : number of participants and i: $1,2,3, \ldots \mathrm{n}$

9) Determination of final weight

This step is the criterion or sub-criteria with the largest normalization value.

\section{RESULTS AND DISCUSSION}

Identification of satisfaction and contributions has been obtained using a questionnaire. Questionnaires given to respondents have met the validity and reliability tests. The company use the data to determine the strategies. It implemented to meet the satisfaction and contribution. The formation of this strategy was discussed with the company. For example, in the aspect of customer satisfaction who want "batik products that are not defective" and "batik products that have a resistance", then from that formed a strategy in the form of "companies producing good quality batik products". After describing each of these satisfactions and contributions, the formed strategy and KPI process can be seen in Table 3.

KPI data from the aspect of company capability obtained from previous studies. Capability aspects include ten KPIs, there are customer growth (KPI 25), customer retention rate (KPI 26), work accident level (KPI 27), revenue per employee (KPI 28), employee turnover rate (KPI 29), community satisfaction (KPI 30), the level of waste treatment (KPI 31), return of investment (KPI 32), net profit margin (KPI 33), and sales growth (KPI 34). Finally, the hierarchy of the five stakeholders and KPIs can be seen in Fig. 3.

In this calculation, the weighting of each criterion is based on its level. Levels on performance prism include level one and level two. Level one compares criteria between stakeholders, and level two compares each KPI from each stakeholder. The company carries out weighting. The Consistency Ratio (CR) value from a comparison between criteria (consumer, employee, community, owner, and supplier) is 0.062 . Because the CR value is less than 0.1 , the weighting between criteria shows consistent or valid results. Likewise, the $C R$ value in the subcriteria shows consistent results because it is less than 0.1. The next step is taken, the performance measurement model is integrated with the Scoring system model, the OMAX (objective matrix) model, whose function is to equalize the scale of each indicator.

Therefore, the achievement of each of the parameters can be known as well as overall company performance. OMAX itself is a method of evaluating company performance developed by Riggs [24]. Where the assessment is carried out in the cafeteria associated with the company. The concept of assessment is to combine several working group performance criteria in a matrix. Each performance criterion has a goal in the form of a special path for improvement and has a weight that is following the number of importance to the organisation's goals.

Table 2. Random index values

\begin{tabular}{ccccccccccc}
\hline $\mathbf{n}$ & $\mathbf{1}$ & $\mathbf{2}$ & $\mathbf{3}$ & $\mathbf{4}$ & $\mathbf{5}$ & $\mathbf{6}$ & $\mathbf{7}$ & $\mathbf{8}$ & $\mathbf{9}$ & $\mathbf{1 0}$ \\
\hline $\mathrm{RI}$ & 0 & 0 & 0.58 & 0.9 & 1.12 & 1.24 & 1.32 & 1.41 & 1.45 & 1.49 \\
\hline
\end{tabular}

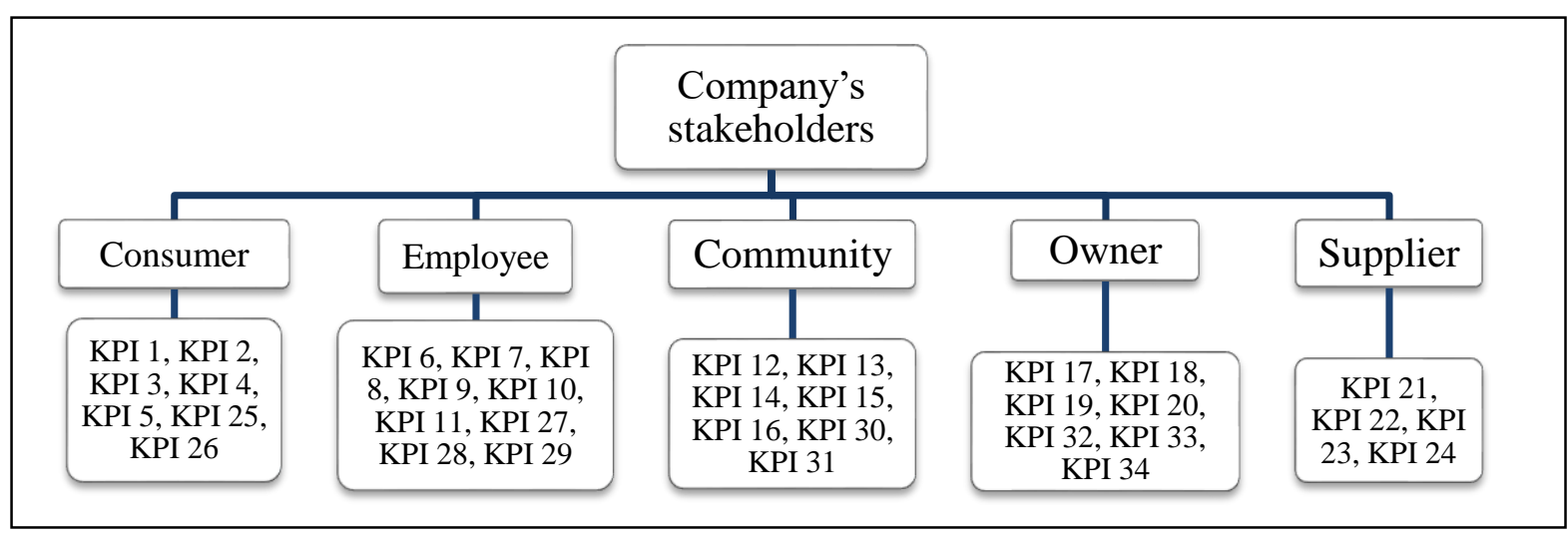

Fig. 3. The hierarchical structure of a company's performance measurement process 
Table 3. Designing KPI from strategy

\begin{tabular}{|c|c|c|}
\hline & Strategy & KPI \\
\hline \multirow[t]{5}{*}{ Consumer } & Producing good quality batik products & Percentage of defective products (KPI 1) \\
\hline & $\begin{array}{l}\text { Displaying product } \\
\text { clearly }\end{array}$ & $\begin{array}{l}\text { Percentage of consumer complaints about } \\
\text { product quality (KPI 2) }\end{array}$ \\
\hline & Deliver the product on time & $\begin{array}{l}\text { Percentage of consumer complaints } \\
\text { against late delivery (KPI 3) }\end{array}$ \\
\hline & $\begin{array}{l}\text { Open a special channel for criticism and } \\
\text { input }\end{array}$ & Number of consumer complaints (KPI 4) \\
\hline & Holding promos at certain times. & Number of promotions (KPI 5) \\
\hline \multirow[t]{6}{*}{ Employee } & $\begin{array}{l}\text { Evaluate positions according to the } \\
\text { ability of workers }\end{array}$ & Evaluation of positions (KPI 6) \\
\hline & $\begin{array}{l}\text { Conducting regular training to improve } \\
\text { the ability of workers }\end{array}$ & Number of training (KPI 7) \\
\hline & Increase employee income & $\begin{array}{l}\text { Percentage of increase in employee } \\
\text { income (KPI 8) }\end{array}$ \\
\hline & $\begin{array}{l}\text { Implement a reward and punishment } \\
\text { system }\end{array}$ & Percentage of employee absences (KPI 9) \\
\hline & Organize a joint discussion forum & Number of discussion meetings (KPI 10) \\
\hline & $\begin{array}{l}\text { Improve or add work facilities for } \\
\text { employees. }\end{array}$ & $\begin{array}{l}\text { Percentage of improvement and addition } \\
\text { of work facilities (KPI 11) }\end{array}$ \\
\hline \multirow[t]{5}{*}{ Community } & $\begin{array}{l}\text { Conducting skills and training programs } \\
\text { for the surrounding community. }\end{array}$ & Number of community training (KPI 12) \\
\hline & $\begin{array}{l}\text { Conducting social service activities } \\
\text { involving residents. }\end{array}$ & Number of social activities (KPI 13) \\
\hline & Employing for surrounding workers. & $\begin{array}{l}\text { Number of workers absorbed from the } \\
\text { surrounding environment (KPI 14) }\end{array}$ \\
\hline & Participating in village meetings. & $\begin{array}{l}\text { Frequency of community assistance (KPI } \\
15)\end{array}$ \\
\hline & $\begin{array}{l}\text { Controlling waste treatment and } \\
\text { disposal properly. }\end{array}$ & $\begin{array}{l}\text { Number of complaints from surrounding } \\
\text { communities regarding waste (KPI 16) }\end{array}$ \\
\hline \multirow[t]{4}{*}{ Owner } & $\begin{array}{l}\text { Complement the facilities needed by the } \\
\text { company. }\end{array}$ & Total number of facilities added (KPI 17) \\
\hline & $\begin{array}{l}\text { Conduct exchange of assets. } \\
\text { Onen a network of cooneration with }\end{array}$ & Total asset turnover (KPI 18) \\
\hline & $\begin{array}{l}\text { certain parties to expand the marketing } \\
\text { network. }\end{array}$ & Number of cooperation (KPI 19) \\
\hline & $\begin{array}{l}\text { Employees in the field of information } \\
\text { technology. }\end{array}$ & Number of IT workers (KPI 20) \\
\hline \multirow[t]{4}{*}{ Supplier } & $\begin{array}{l}\text { Make payments following a } \\
\text { predetermined }\end{array}$ & Late payment ratio (KPI 21) \\
\hline & $\begin{array}{l}\text { time. Provide compensation when } \\
\text { shipping materials. }\end{array}$ & Percentage of delay to lead time (KPI 22) \\
\hline & $\begin{array}{l}\text { Conduct re-examination of raw } \\
\text { materials. }\end{array}$ & $\begin{array}{l}\text { Percentage of quality paint raw materials } \\
\text { (KPI 23) }\end{array}$ \\
\hline & Making a supplier remains a factory & Number of suppliers permanent (KPI 24) \\
\hline
\end{tabular}

OMAX measurement on Performance Prism, grade each level (from 0 to 10 ) uses the value obtained from the aspect of the process by providing an assessment based on the likert scale of the satisfaction questionnaire and the contribution of each stakeholder. The highest number is then entered at level 10. And the lowest number, 1 , is entered at the lowest level, which is level 0 . 
Whereas the granting of 1-9 is an interpolation. Level 0-10 criteria use the traffic light system, i.e. levels 0-2 are in red, levels 3-7 are in yellow and levels 8-10 are green. Then fill in the score table based on the average value of the stakeholder questionnaire and stakeholder contribution. Next is to determine at what level the actual condition is and calculate how much the performance value. The following are the recapitulation of aspects of stakeholder satisfaction, aspects of the contribution of stakeholders, and company capability criteria (Table 4, Table 5, and Table 6).

In the aspect of satisfaction from stakeholders, it was found that the lowest satisfaction value was from employee satisfaction, which was 4.987 (Table 4). This level of employee satisfaction is important because it is the key to the company's business operations. The low score on the aspect of employee satisfaction lies in KPI 6, 9, and 11. The assessment on these KPIs is on evaluating the suitability of the employee's job position with the expertise possessed, the percentage of employee absenteeism, and the improvement of work facilities. In general, HRM (Human Resource Management) practices such as training and development, rewards, job analysis, social support, recruitment and selection, employee relations, and empowerment are said to have a significant relationship with employee performance, as well as employee job satisfaction significantly affect employee performance [25]. Then, HRM practice has no significant effect on employee satisfaction because it depends on employee perceptions [26]. Therefore, a manager's role is needed to strengthen employees' positive HRM perceptions to increase job satisfaction.

The lowest contribution aspect from stakeholders is the contribution from consumers, with a value of 4.98 (Table 5). The desired contribution from customers is mainly on product quality tolerance and delivery delay tolerance (KPI 2 and KPI 3). The way to increase consumer contribution is to create a social media network to increase engagement from SME customers through Social CRM (Customer Relationship Management) [27]. Companies also need to apply the Indonesian National Standard (SNI) for batik using the ISO method to provide added value and provide economic benefits [28].

Based on the value of the lowest level of stakeholder satisfaction is the KPI of employees. The strategy to increase employee satisfaction is to provide job positions to employees according to their abilities, increase income, bonuses, employee facilities, and a joint discussion forum between management and employees. Priority improvements are made to the red colour (KPI 29) and yellow colour KPIs (KPI 25, KPI 26, and KPI 31). KPI 29 gives the only red value on the capability criteria. Therefore, immediate improvement needs to be given for this KPI. It is in line with research conducted by Nurcahyo et al. [29] that the initial stage for priority strategies and development of the batik industry is developing human resources and technological development. Employees are human resources who must receive full attention.

How to solve the higher employee turnover rate? The employee turnover rate starts from the intention to move, which is influenced by leadership behaviour by using the mediation of organizational commitment and the impact of job satisfaction [30]. Therefore, XYZ company needs to use leadership behaviour that is people-oriented rather than task-oriented. Employees must also commit to the organization that can be grown by creating a comfortable working environment. Other KPIs that also need improvements are KPI 25, KPI 26, and KPI 31. Consumer stakeholders for KPI 25 (customer growth) are to add new products that can improve marketing. KPI 26 (customer retention rate) conducts a customer loyalty screening program by offering discounts or cashback for each prospective buyer. Community stakeholders at KPI 31 (the level of waste management) create a batik waste management system that does not pollute the environment.

Table 4. Results summary of satisfaction aspect from stakeholder

\begin{tabular}{llllll}
\hline Stakeholder & Consumer & Employee & Community & Owner & Supplier \\
\hline Total performance value (TPV) & 5.486 & 4.987 & 5.450 & 7.138 & 7.285 \\
Weight stakeholder (WS) & 0.042 & 0.118 & 0.205 & 0.446 & 0.188 \\
TPV*WS & 0.2304 & 0.5885 & 1.1173 & 3.1837 & 1.3696 \\
\hline Total & & & 6.489 & &
\end{tabular}


Table 5. Results summary of contribution aspect from stakeholder

\begin{tabular}{llllll}
\hline Stakeholder & Consumer & Employee & Community & Owner & Supplier \\
\hline Total performance value (TPV) & 4.980 & 5.141 & 5.925 & 7.710 & 7.359 \\
Weight stakeholder (WS) & 0.042 & 0.118 & 0.205 & 0.446 & 0.188 \\
TPV*WS & 0.2092 & 0.6066 & 1.2147 & 3.4385 & 1.3835 \\
\hline Total & & & 6.852 & & \\
\hline
\end{tabular}

Table 6. OMAX scoring based on company capability criteria

\begin{tabular}{lllllllllll}
\hline KPI & $\mathbf{2 5}$ & $\mathbf{2 6}$ & $\mathbf{2 7}$ & $\mathbf{2 8}$ & $\mathbf{2 9}$ & $\mathbf{3 0}$ & $\mathbf{3 1}$ & $\mathbf{3 2}$ & $\mathbf{3 3}$ & $\mathbf{3 4}$ \\
\hline Achievements & $\mathbf{1 1}$ & $\mathbf{1 3}$ & $\mathbf{0}$ & $\mathbf{6 , 7 9 0 , 4 0 8}$ & $\mathbf{1 . 3 8}$ & $\mathbf{8 0}$ & $\mathbf{7 2}$ & $\mathbf{1 0 3 . 7 7}$ & $\mathbf{4 3 . 7}$ & $\mathbf{1 8 . 5 1}$ \\
10 & 25 & 75 & 0 & $6,500,000$ & 0 & 80 & 80 & 100 & 40 & 10 \\
9 & 23 & 66.14 & -0.5 & $6,389,500$ & 0.138 & 79 & 78.86 & 97.16 & 39.87 & 9.32 \\
8 & 21 & 57.29 & -1 & $6,279,000$ & 0.276 & 78 & 77.71 & 94.32 & 39.74 & 8.64 \\
7 & 19 & 48.43 & -1.5 & $6,168,500$ & 0.414 & 77 & 76.57 & 91.48 & 39.60 & 7.96 \\
6 & 17 & 39.57 & -2 & $6,058,000$ & 0.552 & 76 & 75.43 & 88.64 & 39.47 & 7.28 \\
5 & 15 & 30.71 & -2.5 & $5,947,500$ & 0.69 & 75 & 74.29 & 85.8 & 39.34 & 6.61 \\
4 & 13 & 21.86 & -3 & $5,837,000$ & 0.828 & 74 & 73.14 & 82.96 & 39.21 & 5.93 \\
3 & 11 & 13 & -3.5 & $5,726,500$ & 0.966 & 73 & 72 & 80.12 & 39.08 & 5.25 \\
2 & 8.65 & 12.12 & -4 & $5,616,000$ & 1.104 & 72 & 68 & 77.28 & 38.94 & 4.57 \\
1 & 6.29 & 11.25 & -4.5 & $5,505,500$ & 1.242 & 71 & 64 & 74.44 & 38.81 & 3.89 \\
0 & 3.94 & 10.37 & -5 & $5,395,000$ & 1.38 & 70 & 60 & 71.6 & 38.68 & 3.21 \\
\hline Level & 3 & 3 & 10 & 10 & 0 & 10 & 3 & 10 & 10 & 10 \\
Weight & 0.135 & 0.135 & 0.048 & 0.148 & 0.123 & 0.053 & 0.076 & 0.080 & 0.086 & 0.046 \\
Performance & 0.405 & 0.405 & 0.48 & 1.48 & 0 & 0.527 & 0.227 & 0.803 & 0.858 & 0.461 \\
value & 5.646 & & & & & & & & & \\
Total & & & & & & & & & & \\
\hline
\end{tabular}

\section{CONCLUSION}

The influential stakeholders in XYZ company are consumer, employee, community, owner, and supplier. Performance measurement in $\mathrm{XYZ}$ company by using five stakeholders produced 34 KPI. There are seven KPIs from consumer stakeholders, nine KPIs from employees, seven KPIs from community, seven KPIs from owners, and four KPIs from supplier stakeholder. Overall performance value for XYZ company based on the satisfaction aspect is 6.489 . It was 6.582 for the aspect of contributions. From the aspect of company capability, a value of 5.646 is obtained. Therefore, these values show that XYZ company has achieved a fairly good company performance value. It is the scoring criteria using OMAX. If the total measurement is between 0 and 3 , it shows the company's performance is deficient. If the total measurement is between 3.01 to 8 , the company's performance is fairly good, and if the total measurement is more than 8 to 10 shows good company performance.

To overcome the measurement value of the company's performance which is still in the yellow and red values, the company should meet the recommendations that have been given. KPI 29 (employee turnover ratio) that gives the only red value on the capability criteria must receive full attention to be resolved. Companies must be able to create people-oriented leadership behaviour to result in employee satisfaction and organizational commitment from employees to the company.

Future research can implement the recommendations given and makes financial calculations. It is hoped that it can continue to develop strategic goals that are adjusted to company procedures and policies so that the company's goals can be maximally achieved. Another research is the application of the performance prism method in other SMEs. 


\section{ACKNOWLEDGMENT}

This research was supported by the Industrial Engineering Department, Faculty of Technology Industry, Universitas Islam Indonesia, Yogyakarta, Indonesia.

\section{REFERENCES}

[1] E. Steelyana, "Batik, A Beautiful Cultural Heritage that Preserve Culture and Supporteconomic Development in Indonesia," Binus Bus. Rev., vol. 3, no. 1, pp. 116-131, May 2012, doi: 10.21512/bbr.v3i1.1288.

[2] A. M. Kanu and I. Sesay, "The practice of performance measurement in small and medium enterprises: Empirical evidence from a developed economy perspective," Q. J. Bus. Stud., vol. 2, no. 3, pp. 160-173, 2016.

Available: https://ideas.repec.org/a/rss/jnljbs/v2i3p5. html.

[3] I. Hristov and A. Chirico, "The Limits of the Balanced Scorecard," Open J. Soc. Sci., vol. 04, no. 11, pp. 53-58, 2016, doi: 10.4236/jss.2016.411004.

[4] F. Simbolon, "Perbandingan Sistem Pengukuran Kinerja Perusahaan," Binus Bus. Rev., vol. 6, no. 1, pp. 91-100, May 2015, doi: 10.21512/bbr.v6i1.991.

[5] M. Najmi, M. Etebari, and S. Emami, "A framework to review Performance Prism," Int. J. Oper. Prod. Manag., vol. 32, no. 10, pp. 1124-1146, Jan. 2012, doi: 10.1108/01443571211274486.

[6] I. Đalić, J. Ateljević, Ž. Stević, and S. Terzić, "An integrated swot-fuzzy piprecia model for analysis of competitiveness in order to improve logistics performances," Facta Univ. Ser. Mech. Eng., vol. 18, no. 3, pp. 439-451, Oct. 2020, doi: 10.22190/FUME200325029D.

[7] A. Neely, C. Adams, and P. Crowe, "The performance prism in practice," Meas. Bus. Excell., vol. 5, no. 2, pp. 6-13, Jan. 2001, doi: 10.1108/13683040110385142.

[8] A. Neely and C. Adams, Perspectives on performance: the performance prism. UK: Centre for Business Performance, Cranfield School of Management, 2000. Available:

https://www.exinfm.com/pdffiles/prismart icle.

[9] R. S. Kaplan and D. P. Norton, Strategy
Maps: Converting Intangible Assets Into Tangible Outcomes. Cambridge, MA: Harvard Business School Press, 2004. Available:

https://books.google.co.id/books?id=vCnh Fu52rosC.

[10] Y. Setiawannie and T. Rahmania, "Performance measurement of public hospitals through the integration of SWOT and balanced scorecard," J. Sist. dan Manaj. Ind., vol. 3, no. 2, pp. 76-88, Dec. 2019, doi: 10.30656/jsmi.v3i2.1472.

[11] R. N. Anthony and V. Govindarajan, Sistem Pengendalian Manajemen. 2005. Available:

https://opac.perpusnas.go.id/DetailOpac.a spx?id=681471.

[12] M. Journeault, A. Perron, and L. Vallières, "The collaborative roles of stakeholders in supporting the adoption of sustainability in SMEs," J. Environ. Manage., vol. 287, p. 112349, 2021, doi: 10.1016/j.jenvman.2021.112349.

[13] M. Budijanto, Y. Priyandari, and S. E. Sari, "Perancangan Key Performance Indicators (KPI) Menggunakan Metode Performance Prism (Studi Kasus di Batik Putra Bengawan)," Performa Media Ilm. Tek. Ind., vol. 11, no. 2, pp. 153-158, 2012. Available:

https://jurnal.uns.ac.id/performa/article/vi ew/13944.

[14] E. Severgnini, E. V. C. Galdamez, and R. R. Camacho, "Applicability of Performance Prism in SMEs: a multiple case study," Gestão \& Produção, vol. 26, no. 4, p. e3014, 2019, doi: 10.1590/0104530x3014-19.

[15] M. A. Ilgin, S. M. Gupta, and O. Battaïa, "Use of MCDM techniques in environmentally conscious manufacturing and product recovery: State of the art," $J$. Manuf. Syst., vol. 37, pp. 746-758, 2015, doi: 10.1016/j.jmsy.2015.04.010.

[16] M. Yazdani and F. R. Graeml, "VIKOR and its Applications," Int. J. Strateg. Decis. Sci., vol. 5, no. 2, pp. 56-83, Apr. 2014, doi: 10.4018/ijsds.2014040105.

[17] W. S. S. Patria, O. S. Suharyo, and A. D. Susanto, "Performance Assessment of PT. $\mathrm{X}$ Automotive Companies Using Performance Prism and Analytical Hierarchy Process (AHP)," Int. J. Acad. 
Manag. Sci. Res., vol. 2, no. 8, pp. 11-18, 2018. Available: https://philpapers.org/rec/SENPAO.

[18] R. P. Sari, "Integration of Key Performance Indicator into the Corporate Strategic Planning: Case Study at PT. Inti Luhur Fuja Abadi, Pasuruan, East Java, Indonesia," Agric. Agric. Sci. Procedia, vol. 3, pp. 121-126, 2015, doi: 10.1016/j.aaspro.2015.01.024.

[19] T. L. Saaty and L. G. Vargas, Models, Methods, Concepts \&amp; Applications of the Analytic Hierarchy Process, vol. 175. Boston, MA: Springer US, 2012. doi: 10.1007/978-1-4614-3597-6.

[20] C. Z. M. Jamil and R. Mohamed, "The Effect of Management Control System on Performance Measurement System at Small Medium Hotel in Malaysia," Int. J. Trade, Econ. Financ., vol. 4, no. 4, pp. 202-208, 2013, doi: 10.7763/IJTEF.2013.V4.286.

[21] D. A. Garvin, Managing Quality: The Strategic and Competitive Edge. New York: The Free Press, 1988. Available: https://books.google.co.id/books?id=KLWY2qgSHwC.

[22] F. Luthans, Perilaku Organisasi, 10th ed. Yogyakrata: Andy, 2006. Available: https://opac.perpusnas.go.id/DetailOpac.a spx?id=672492.

[23] T. L. Saaty, "The Analytical Hierarchy Process in Conflict Management," Int. J. Confl. Manag., vol. 1, no. 1, pp. 47-68, Jan. 1990, doi: 10.1108/eb022672.

[24] J. L. Riggs and J. Riggs, Production Systems: Planning, Analysis, and Control. Wiley, $1981 . \quad$ Available: https://books.google.co.id/books?id=18k mAQAAMAAJ.
[25] M. S. Mira, Y. V. Choong, and C. K. Thim, "The effect of HRM practices and employees' job satisfaction on employee performance," Manag. Sci. Lett., vol. 9, no. 6, pp. 771-786, 2019, doi: 10.5267/j.msl.2019.3.011.

[26] L. Hauret, L. Martin, N. Omrani, and D. R. Williams, "How do HRM practices improve employee satisfaction?," Econ. Ind. Democr., p. 0143831X20962199, Oct. 2020, doi: 10.1177/0143831X20962199.

[27] C. C. J. Cheng and E. C. Shiu, "How to enhance SMEs customer involvement using social media: The role of Social CRM," Int. Small Bus. J., vol. 37, no. 1, pp. 22-42, May 2018, doi: $10.1177 / 0266242618774831$.

[28] Phalitatyasetri, F. Fahma, and W. Sutopo, "The economic benefits of the implementation of batik Indonesian National Standard (SNI) by ISO methodology - Economic benefit standard (EBS) approach," in AIP Conference Proceedings, 2020, vol. 2217, no. 1, p. 030101, doi: 10.1063/5.0000718.

[29] R. Nurcahyo, F. Paramitha, D. S. Gabriel, and D. A. Ramdha, "Strategy Prioritization and Development for Batik Industry," in 2018 IEEE 5th International Conference on Engineering Technologies and Applied Sciences (ICETAS), Nov. 2018, pp. 1-6, doi: 10.1109/ICETAS.2018.8629108.

[30] C. Mathieu, B. Fabi, R. Lacoursière, and L. Raymond, "The role of supervisory behavior, job satisfaction and organizational commitment on employee turnover," J. Manag. Organ., vol. 22, no. 1, pp. 113-129, Jan. 2016, doi: 10.1017/jmo.2015.25. 